\title{
APLIKASI TEKNOLOGI ELEKTROLISIS PLASMA PADA PROSES PRODUKSI KLOR-ALKALI
}

\author{
Nelson Saksono*, Fakhrian Abqari, Setijo Bismo \\ Departemen Teknik Kimia, Fakultas Teknik \\ Universitas Indonesia \\ Kampus UI, Depok 16424 \\ Email: nelson@che.ui.ac.id
}

\begin{abstract}
Abstrak
Industri klor-alkali merupakan salah satu industri penting dalam industri kimia dengan konsumsi energi listrik yang tinggi karena proses produksinya menggunakan metode elektrolisis. Elektrolisis plasma merupakan proses elektrolisis dengan tegangan yang jauh lebih tinggi sehingga terbentuk lecutan api listrik pada larutan elektrolit. Metode ini dapat diterapkan dalam aplikasi produksi klor-alkali dan mampu mengurangi konsumsi energi listrik hingga beberapa kali lipat. Penelitian ini bertujuan untuk menguji metode elektrolisis plasma dalam menghasilkan gas klor serta mengukur konsumsi energi listrik yang dibutuhkan dalam proses produksi klor-alkali. Penelitian dilakukan menggunakan reaktor elektrolisis plasma yang telah dilengkapi elektroda dan sistem pendingin. Variabel proses yang diamati meliputi tegangan, konsentrasi $\mathrm{NaCl}$, dan kedalaman anoda. Hasil percobaan menunjukkan kenaikan produksi gas klor dengan meningkatnya tegangan, konsentrasi $\mathrm{NaCl}$ dan kedalaman anoda. Produksi gas klor tertinggi adalah sebesar 1,44 mmol yang diperoleh selama 15 menit proses pada tegangan $400 \mathrm{~V}$ dan konsentrasi $\mathrm{NaCl}$ 0,15 $\mathrm{M}$ dimana posisi anoda pada permukaan larutan. Konsumsi energi listrik mencapai $284 \mathrm{~kJ} / \mathrm{mmol} \mathrm{Cl}_{2}$ yang berarti 38 kali lebih rendah dibanding proses elektrolisis dalam konfigurasi reaktor yang sama.
\end{abstract}

Kata kunci: elektrolisis, elektrolisis plasma, produksi klor-alkali

\begin{abstract}
PLASMA ELECTROLYSIS TECHNOLOGY APPLICATIONS IN CHLOR-ALKALI PROCESS PRODUCTION. Chlor-alkali industry sector is one of the important industrial sectorsin chemical industry. However, the chlor-alkali industry is one of the industry sectors that consume the most electrical energy due to the production using the methodof electrolysis. Plasma electrolysis is an electrolysis process with high voltage so that produce the glow discharge plasma in electrolyte solution. This method can be applied in the production of chlor-alkali and can reduce energy consumption several times. This research is aimed to observe the plasma electrolysis method in producing chlorine gas and also to measure the electricity consumption needed in chlor-alkali production process. This study was conducted by using plasma electrolysis reactor equipped by electrodes and cooling system. Process variables observed are voltage, $\mathrm{NaCl}$ concntration, and anode depth. Result of this research shows that the increase of all variables will cause the increase of chlorine gas production. The highest chlorine gas production is $1.44 \mathrm{mmol}$ for 15 minutes at $400 \mathrm{~V}$ and $0.15 \mathrm{M} \mathrm{NaCl}$ solution where the anode position is at the surface of solution. Energy consumption of the process reaches $284 \mathrm{~kJ} / \mathrm{mmol} \mathrm{Cl}_{2}$, which is 38 times lower than electrolysis process in the same reactor configuration.
\end{abstract}

Keywords: electrolysis, plasma electrolysis, production of chlor-alkali

*penulis korespondensi 


\section{PENDAHULUAN}

Sektor industri klor-alkali merupakan sektor industri penting pada industri kimia karena berperan sebagai pemasok bahan baku sektor industri lainnya. Di Eropa, industri klor-alkali menyokong sekitar 55\% industri kimia dan farmasi serta memberikan keuntungan hingga 660 miliar euro pada tahun 2009 (Euro Chlor, 2010). Bahan baku utama yang digunakan dalam produksi kloralkali adalah garam $(\mathrm{NaCl})$, air, dan tenaga listrik. Produk yang dihasilkan berupa soda api $(\mathrm{NaOH})$, hidrogen $\left(\mathrm{H}_{2}\right)$, dan klor $\left(\mathrm{Cl}_{2}\right)$. Sementara produk sampingnya berupa ion hipoklorit dan klorat (Bommaraju dkk, 2011).

Elektrolisis adalah metode pemisahan ikatan-ikatan senyawa dengan mengalirkan arus listrik pada ikatan senyawa tersebut. Senyawa ionik, seperti garam $\mathrm{NaCl}$, terurai pada pelarut seperti air, dan membentuk ionion dalam larutan. Arus listrik dialirkan diantara dua elektroda inert dalam larutan. Masing-masing elektroda mengikat ion-ion yang memiliki muatan berbeda sehingga ion bermuatan negatif akan menuju anoda dan ion bermuatan positif akan menuju katoda. Reaksi elektrolisis $\mathrm{NaCl}$ (Brine Electrolysis) yang banyak dipakai saat ini untuk menghasilkan klor-alkali membutuhkan energi listrik yang sangat tinggi (Abdel-Aal dan Hussein, 1993).

Konsumsi energi rata-rata pada proses elektrolisis klor adalah sekitar 3,3 MWh per unit elektrokimia (ECU), sehingga komponen biaya listrik mencapai hingga $70 \%$ dari harga penjualan. Oleh sebab itu, penurunan konsumsi listrik dalam reaksi elektrokimia pada produksi klor-alkali menjadi topik yang sangat menarik. Untuk itu dibutuhkan suatu metode lain yang lebih efisien yang dapat menekan konsumsi listrik dalam proses produksi klor-alkali (Santorelli dkk, 2009).

Elektrolisis plasma merupakan metode alternatif yang menjanjikan karena dapat menekan konsumsi energi listrik yang sangat signifikan dibanding proses elektrolisis. Prinsip elektrolisis plasma serupa dengan elektrolisis, namun dilakukan pada kondisi tegangan tinggi sehingga menimbulkan pancaran plasma (glow discharge plasma). Dengan adanya plasma, maka kinetika didalam larutan menjadi meningkat, sehingga akan terbentuk spesi aktif yang membuat suatu reaksi akan berlangsung lebih cepat dengan konversi yang lebih besar (Saksono dkk, 2011; Mizuno dkk, 2005).

\section{METODE}

Penelitian ini bertujuan untuk melihat kinerjametode elektrolisis plasma dalam mengkonversi larutan $\mathrm{NaCl}$ menjadi klor dengan mengukur jumlah gas klor yang dihasilkan dan konsumsi energi listriknya.

Reaktor yang digunakan adalah reaktor sistem batch yang dibuat dari housing filter akrilik yang dilengkapi dengan elektroda grafit dengan panjang $5 \mathrm{~cm}$ dan diameter 0,5 cm sebagai anoda. Sebagai katoda digunakan pipa stainless steel dengan panjang $1 \mathrm{~m}$ berbentuk spiral dengan diameter dalam 0,5 $\mathrm{cm}$ dan sekaligus berfungsi sebagai pendingin dengan mengalirkan air pendingin pada bagian dalam pipa katoda. Sumber listrik terhubung ke regulator geser 3kVA yang dihubungkan dengan jembatan dioda untuk membuat arus listrik menjadi searah (DC). Arus listrik diukur dan dicatat dari ampere meter Yuhua A830L.

Konfigurasi peralatan ditunjukkan pada Gambar 1. Produk gas dari reaktor akan dimasukan ke dalam larutan KI 2\%. KI akan mengikat gas klor dan bereaksi membentuk iodin yang menghasilkan warna jingga dalam larutan KI. Kemudian, larutan KI dititrasi dengan larutan $\mathrm{Na}_{2} \mathrm{~S}_{2} \mathrm{O}_{3}$ 0,005M. Pengukuran pH larutan akhir dilakukan untuk memeriksa produksi soda api $(\mathrm{NaOH})$.

Konsumsi energi per satuan produk $\mathrm{Cl}_{2}$ dihitung dengan menggunakan data arus dan jumlah mol gas klor yang terukur. Arus akan tercatat dengan amperemeter pada tegangan tertentu sedangkan gas klor yang terukur berada dalam rentang waktu tertentu (15 menit). Maka konsumsi energi (kJ) dapat dihitung sebagai hasil kali tegangan (volt) dengan arus (Ampere) dan waktu proses (detik).

Variasi dalam penelitian ini meliputi konsentrasi, tegangan, dan kedalaman anoda. Konsentrasi divariasikan dari 0,05 M-0,15 M, tegangan divariasikan dari $300 \mathrm{~V}-400 \mathrm{~V}$, dan kedalaman anoda divariasikan sampai $2 \mathrm{~cm}$ di bawah permukaan. 


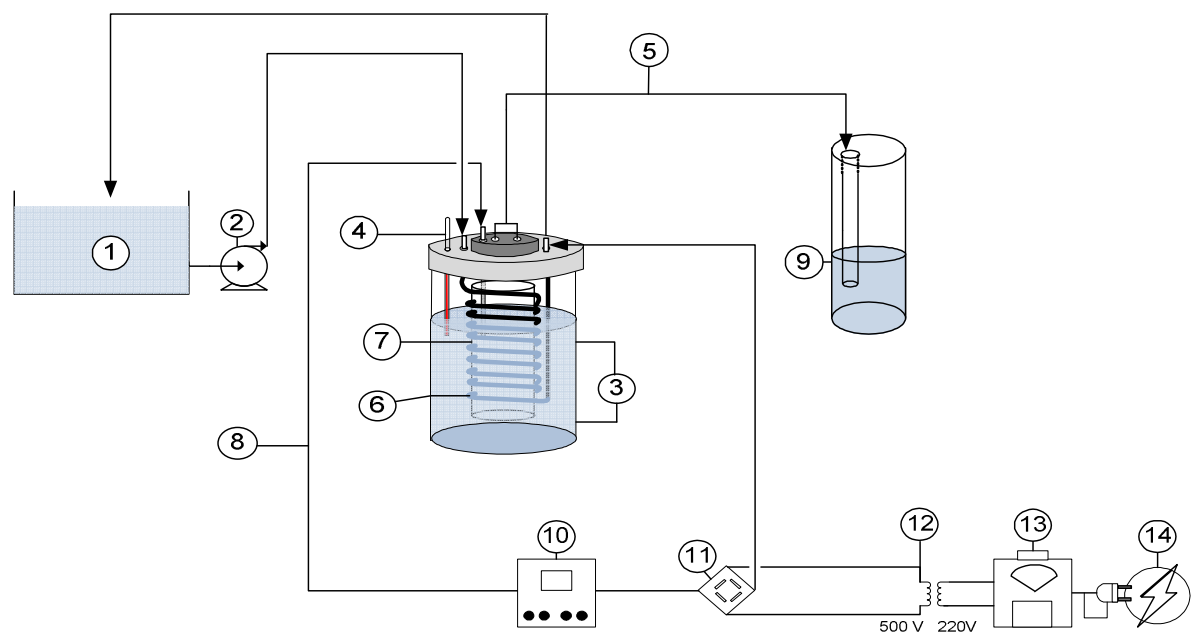

Keterangan gambar :

1. Air Pendingin

2. Pompa

3. Larutan $\mathrm{NaCl}$

4. Termometer
5. Produk Gas Klor

6. Katoda (Koil Pendingin)

7. Penghalang Akrilik

8. Anoda

9. Larutan $\mathrm{KI}$
10. Ampere-meter

11. Jembatan Dioda

12. Transformer

13. Slide Regulator

14. Sumber Listrik

Gambar 1. Konfigurasi peralatan elektrolisis plasma

HASIL DAN PEMBAHASAN

Pengaruh Tegangan dan Konsentrasi terhadap Produksi Klor dan Konsumsi Energi

Gambar 2 menunjukkan terjadi kenaikan produksi gas klor dengan meningkatnya tegangan pada konsentrasi 0,05 $\mathrm{M} \mathrm{NaCl}$ dan suhu 40-50 ${ }^{\circ} \mathrm{C}$ selama 15 menit operasi. Tegangan tinggi akan memberikan energi yang tinggi sehingga elektron dalam ion klor yang terbentuk di sekitar anoda tereksitasi yang menyebabkan terbentuknya radikal klor $(\mathrm{Cl} \bullet)$ dan kemudian bereaksi untuk membentuk gas klor $\left(\mathrm{Cl}_{2}\right)$.

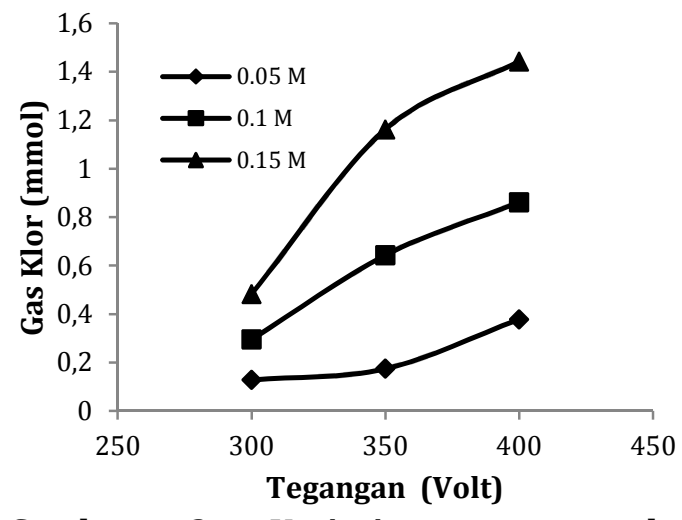

Gambar 2. Variasi tegangan dan konsentrasi terhadap produksi klor pada larutan $\mathrm{NaCl}$ 0,05 $\mathrm{M}$; 0,1 M; dan 0,15 M selama 15 menit dan suhu $40-50{ }^{\circ} \mathrm{C}$
Tegangan tinggi juga menyebabkan terbentuknya radikal $\mathrm{OH}(\bullet \mathrm{OH})$ di sekitar anoda yang ikut mendorong terbentuknya gas klor melalui suatu mekanisme reaksi radikal. Semakin tinggi tegangan yang diberikan, maka elektron yang tereksitasi dari ion $\mathrm{Cl}^{-}$dan produksi $\bullet \mathrm{OH}$ akan lebih banyak sehingga membuat produksi $\mathrm{Cl}_{2}$ meningkat secara signifikan.

Gambar 2 juga menunjukkan bahwa peningkatan konsentrasi $\mathrm{NaCl}(0,05 \mathrm{M} ; 0,1 \mathrm{M}$; dan $0,15 \mathrm{M})$ menyebabkan peningkatan produksi gas klor pada setiap tegangan yang diberikan. Peningkatan konsentrasi $\mathrm{NaCl}$ berarti jumlah ion $\mathrm{Cl}^{-}$yang terbentuk di sekitar anoda juga meningkat dan selanjutnya bereaksi dengan radikal $\mathrm{OH}$ atau pijaran plasma membentuk membentuk gas klor $\left(\mathrm{Cl}_{2}\right)$. $\mathrm{NaCl}$ dengan konsentrasi yang tinggi menunjukkan bahwa konduktivitas larutan tinggi (Jin dkk., 2010). Hal tersebut akan membuat elektron bergerak dengan mudah di dalamlarutan yang dapat berubah menjadi elektron berenergi tinggi. Elektron ini akan memicu terbentuknya spesies radikal seperti $\mathrm{OH} \bullet$ dan $\bullet \mathrm{Cl}$. Spesies-spesies tersebut akan membuat produksi gas klor dalam elektrolisis plasma meningkat (Jin dkk, 2010).

Gambar 2 menunjukkan kenaikan tegangan pada konsentrasi rendah $(0,05 \mathrm{M})$ kurang signifikan meningkatkan produksi gas klor dibandingkan dengan larutan dengan 
konsentrasi 0,1 M dan 0,15 M. Hal ini dapat disebabkan oleh populasi ion $\mathrm{Cl}^{-}$cenderung lebih kecil pada larutan dengan konsentrasi rendah. Selain itu, konduktivitas pada larutan 0,05 $\mathrm{M}$ jauh lebih rendah dibandingkan dengan konsentrasi $0,1 \mathrm{M}$ dan 0,15 M. Hal ini mengakibatkan efek pemanasan Joule yang terbentuk lebih kecil sehingga menekan pembentukan plasma (plasma yang terbentuk kecil). Oleh sebab itu kenaikan tegangan terhadap produk gas klor pada larutan 0,05 M tidak setinggi kenaikan produk gas klor pada konsentrasi 0,1 M dan 0,15 M.

Kenaikan tegangan pada percobaan ini menurunkan konsumsi energi listrik per mmol produk klor yang dihasilkan seperti yang ditunjukkan pada Gambar 3. Pada konsentrasi $\mathrm{NaCl} 0,05 \mathrm{M}$, konsumsi energi per klor yang diproduksi untuk setiap tegangan $(300 \mathrm{~V}, 350 \mathrm{~V}$, dan $400 \mathrm{~V})$ masing masing sebesar $2.525 \mathrm{~kJ} / \mathrm{mmol} \mathrm{Cl}_{2}, 1.687 \mathrm{~kJ} / \mathrm{mmol} \mathrm{Cl}_{2}$, dan $987 \mathrm{~kJ} / \mathrm{mmol} \mathrm{Cl}_{2}$. Untuk konsentrasi 0,1 $\mathrm{M}$, konsumsi energinya sebesar 1.122 $\mathrm{kJ} / \mathrm{mmol} \mathrm{Cl}_{2}, 533 \mathrm{~kJ} / \mathrm{mmol} \mathrm{Cl}_{2}$, dan 510 $\mathrm{kJ} / \mathrm{mmol} \mathrm{Cl} \mathrm{Cl}_{2}$ untuk masing-masing tegangan. Sedangkan untuk konsentrasi $0,15 \quad \mathrm{M}$ konsumsi energinya sebesar $631 \mathrm{~kJ} / \mathrm{mmol} \mathrm{Cl}_{2}$; $293 \mathrm{~kJ} / \mathrm{mmol} \mathrm{Cl}{ }_{2}$; dan $284 \mathrm{~kJ} / \mathrm{mmol} \mathrm{Cl}$. Energi yang digunakan untuk memicu elektron tereksitasi lebih tinggi bila beda potensial semakin tinggi (tegangan meningkat). Ini akan membuat pembentukan spesies radikal meningkat yang mengakibatkan semakin cepat terbentuknya gas klor.

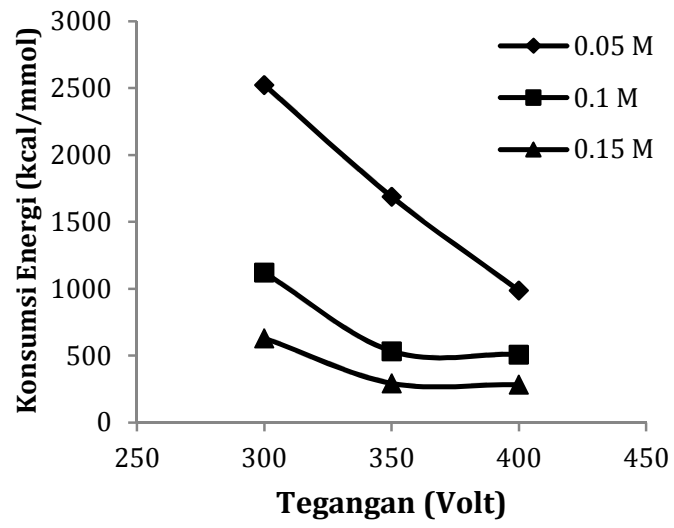

Gambar 3. Hubungan variasi tegangan dan konsentrasi $\mathrm{NaCl}$ terhadap konsumsi energi selama 15 menit operasi dan suhu 40-50 ${ }^{\circ} \mathrm{C}$

Gambar 3 menjelaskan semakin tinggi konsentrasi maka konsumsi energi menjadi semakin rendah. Konsentrasi yang lebih tinggi membuat jumlah klor dalam larutan menjadi lebih banyak. Peningkatan jumlah klor akan meningkatkan jumlah radikal klor karena eksitasi elektron dari ion klor yang kemudian meningkatkan jumlah gas klor $\left(\mathrm{Cl}_{2}\right)$ yang dihasilkan. Selain itu, naiknya konsentrasi $\mathrm{NaCl}$ menyebabkan meningkatnya konduktivitas larutan. Hal ini akan membuat perpindahan ion menjadi lebih cepat sehingga kemungkinan molekul untuk berbenturan meningkat dan reaksi untuk menghasilkan gas klor menjadi lebih cepat (Moustakas dkk., 2005).

Proses pembentukan plasma dalam elektrolisis plasma dimulai dengan proses elektrolisis dimana kenaikan tegangan menyebabkan naiknya suhu larutan yang disebut efek pemanasan Joule (Moustakas dkk., 2005). Suhu yang tinggi pada larutan menyebabkan hambatan di dalam larutan menjadi semakin tinggi, sehingga arus menjadi rendah. Dengan semakin tingginya tegangan maka disekitar anoda banyak terbentuk selubung uap air yang menghambat aliran elektron. Ketika mencapai tegangan kritis maka sebagian elektron (pada ion $\mathrm{Cl}^{-}$) disekitar anoda akan mengalami loncatan (eksitasi) dari larutan menuju anoda yang ditandai dengan terbentuknya pijaran plasma. Semakin tinggi tegangan maka akan semakin banyak elektron yang tereksitasi. Hal ini ditandai dengan ukuran dan pancaran plasma yang semakin besar. Banyaknya elektron yang tereksitasi (elektron berenergi tinggi) menyebabkan terbentuknya spesies reaktif seperti $\mathrm{OH} \bullet$ dan $\bullet \mathrm{Cl}$ yang dapat mendorong pembentukan gas klor menjadi lebih cepat.

Kedua hal tersebut membuat konsumsi listrik yang dinyatakan dalam satuan energi per produk gas klor yang dihasilkan menjadi lebih rendah seiring dengan meningkatnya tegangan dan juga konsentrasi.

\section{Pengaruh Kedalaman Anoda pada Produksi Gas Klor dan Konsumsi Energi}

Gambar 4 menunjukkan bertambahnya kedalaman anoda di larutan menyebabkan meningkatnya arus listrik. Besarnya arus saat anoda berada di permukaan larutan adalah sekitar 0,46 A. Sedangkan untuk kedalaman 1 $\mathrm{cm}$ besarnya arus rata rata dalah 1,19 A dan pada kedalaman $2 \mathrm{~cm}$ besarnya arus adalah 2,26 A.

Arus yang semakin besar disebabkan oleh semakin luasnya permukaan anoda yang terkontak dengan larutan sehingga elektron 
mudah berpindah dari larutan ke anoda. Dalam penelitian yang dilakukan oleh Sengupta dan Singh (1994), dinyatakan bahwa pada elektroda yang lebih pendek dan lebih kecil, densitas arus akan menjadi lebih besar. Densitas arus yang semakin besar ini mengakibatkan semakin meningkatnya energi kalor (Joule Heating Effect) dan menghasilkan lebih banyak uap per luas permukaan elektroda.Hal ini disebabkan oleh adanya eksitasi elektron akibat adanya perbedaan potensial yang tinggi antara anoda dengan larutan.

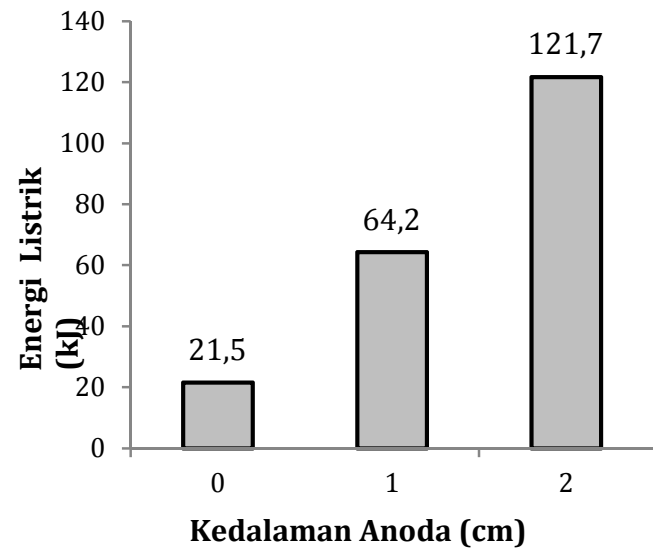

Gambar 4. Pengaruh kedalaman anoda terhadap daya listrik pada larutan $\mathrm{NaCl} \mathrm{0,1}$ $M$ dan tegangan $300 \mathrm{~V}$ selama 5 menit dengan suhu $40-50{ }^{\circ} \mathrm{C}$

Sengupta dan Singh (1994) pada percobaan larutan elektrolit $\mathrm{KOH}$ mendapatkan bahwa semakin luas permukaan anoda yang terkontak dengan larutan (anoda semakin dalam masuk kelarutan), maka semakin besar plasma yang terbentuk dan arus listrik meningkat serta berfluktuasi.

Gambar 5 menunjukkan peningkatan jumlah gas klor yang dihasilkan dengan bertambahnya kedalaman anoda. Untuk anoda di permukaan larutan $(0 \mathrm{~cm})$ diperoleh banyaknya gas klor sebesar $0,023 \mathrm{mmol}$ sementara pada kedalaman anoda $1 \mathrm{~cm}$ dan 2 $\mathrm{cm}$, gas klor yang dihasilkan masing-masing sebesar 0,041 dan 0,185 mmol. Kedalaman ini akan berpengaruh pada produksi selubung uap pada permukaan anoda. Dengan semakin luas permukaan anoda yang terselubungi uap, maka akan memicu pijaran plasma lebih besar (Jin dkk, 2010). Hal ini akan membuat lebih banyak senyawa yang terdekomposisi menjadi spesi reaktif berupa radikal maupun ion yang selanjutnya akan membentuk produk, antara lain berupa gas klor.
Bertambah luasnya permukaan kontak juga menyebabkan proses elektrolisis meningkat dalam larutan sehingga berdampak pada konsumsi listrik yang meningkat tajam seperti yang ditunjukkan pada Gambar 4 .

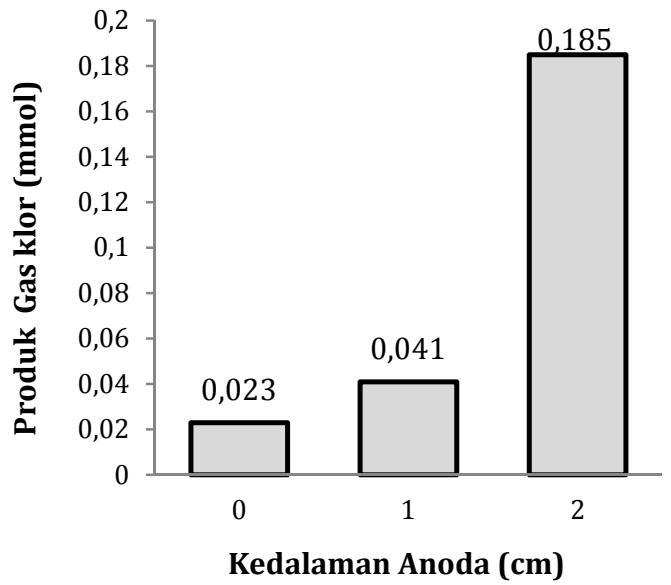

Gambar 5. Pengaruh kedalaman anoda terhadap produksi $\mathrm{Cl}_{2}$ pada larutan $\mathrm{NaCl}$ $0,1 \mathrm{M}$, tegangan $300 \mathrm{~V}$, selama 5 menit dan suhu $40-50{ }^{\circ} \mathrm{C}$

Gambar 6 menunjukkan konsumsi listrik terendah per $\mathrm{mmol}_{2} \mathrm{Cl}_{2}$ yang dihasilkan didapat pada kedalaman anoda $2 \mathrm{~cm}$. Hasil penelitian ini dapat disimpulkan bahwa dengan konsumsi energi paling besar yaitu pada kedalaman anoda $2 \mathrm{~cm}$ (Gambar 4) menghasilkan efisiensi yang paling baik (Gambar 6). Hal ini dikarenakan produk yang dihasilkan jauh lebih besar dibandingkan dengan kedalaman $1 \mathrm{~cm}$ dan $0 \mathrm{~cm}$.

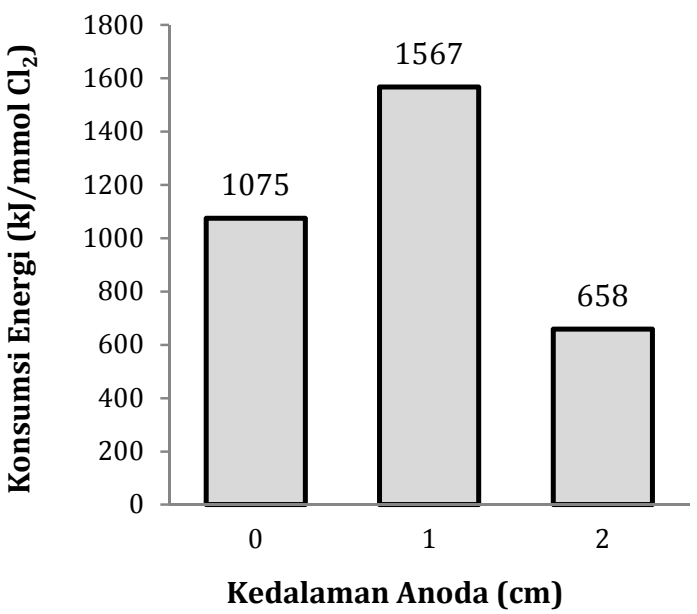

Gambar 6. Pengaruh kedalaman anoda terhadap konsumsi energi pada larutan $\mathrm{NaCl} 0,1 \mathrm{M}$ dan tegangan $300 \mathrm{~V}$ selama 5 menit dengan suhu $40-50{ }^{\circ} \mathrm{C}$ 
Pengaruh Tegangan dan Konsentrasi Larutan terhadap Produksi NaOH

$\mathrm{NaOH}$ merupakan produk samping dari proses elektrolisis plasma larutan $\mathrm{NaCl}$. Dalam penelitian ini, $\mathrm{NaOH}$ diidentifikasi dengan melihat $\mathrm{pH}$ larutan akhir setelah proses elektrolisis plasma dilakukan. Berdasarkan Gambar 7, diperoleh hasil bahwa semakin besar tegangan maka $\mathrm{pH}$ larutan yang dihasilkan semakin menurun. Disisi lain, semakin tinggi konsentrasi larutan $\mathrm{NaCl}$, maka semakin tinggi pula $\mathrm{pH}$ larutan akhir yang dihasilkan. Pada konsentrasi 0,05 M, pH pada masing-masing tegangan 300,350 , dan $400 \mathrm{~V}$ sebesar 9,83; 9,58; dan 9,23. Pada konsentrasi 0,1 M diperoleh pH 10,49; 10,74; dan 10,1 dan pada konsentrasi $0,15 \mathrm{M}$ diperoleh $\mathrm{pH}$ sebesar 11,$31 ; 10,91$; dan 10,75 untuk masing-masing tegangannya.

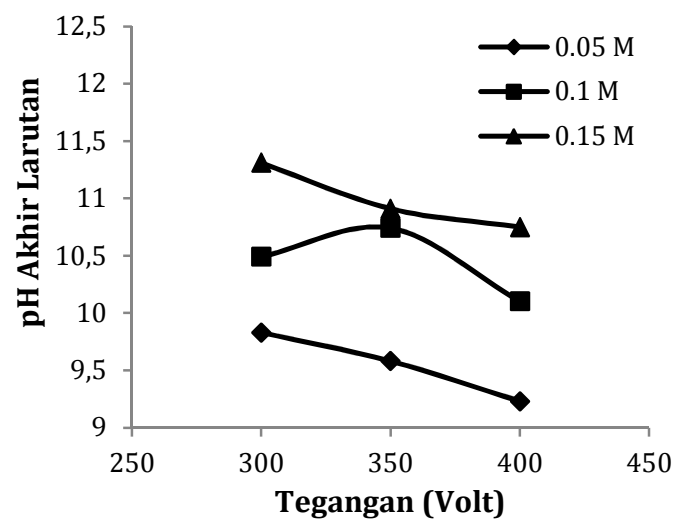

Gambar 7. Pengaruh tegangan pada $\mathbf{p H}$ larutan akhir pada larutan $\mathrm{NaCl} 0,05 \mathrm{M} ; 0,1$ $M$; dan 0,15 $M$ selama 15 menit dengan suhu $40-50{ }^{\circ} \mathrm{C}$

$\mathrm{NaOH}$ dapat terbentuk karena adanya reaksi antara ion $\mathrm{OH}^{-}$dengan ion $\mathrm{Na}^{+}$melalui suatu mekanisme reaksi pada katoda. Ion $\mathrm{Na}^{+}$ yang terbentuk dari dekomposisi senyawa $\mathrm{NaCl}$ pada anoda karena adanya plasma berpindah menuju katoda (elektroda negatif) bersama dengan ion-ion lain. Setelah tiba di katoda, ion-ion $\mathrm{Na}^{+}$ini selanjutnya bereaksi dengan ion hidroksil $\left(\mathrm{OH}^{-}\right)$yang terdapat di dalam larutan membentuk suatu senyawa baru, yaitu $\mathrm{NaOH}$ (O’Brien dkk, 2005). Terbentuknya senyawa $\mathrm{NaOH}$ ini akan membuat $\mathrm{pH}$ di dalam lautan menjadi tinggi dikarenakan sifat $\mathrm{NaOH}$ yang basa kuat. Oleh karena itu, setelah proses elektrolisis plasma berlangsung dalam rentang waktu terntentu, $\mathrm{pH}$ di larutan menjadi tinggi dibandingkan $\mathrm{pH}$ awal larutan yang berada di kisaran 6-7.
Kecenderungan dari Gambar 7 adalah semakin tingginya konsentrasi, maka semakin tinggi pH pada kondisi tegangan yang sama. Hal ini dikarenakan dengan semakin tingginya konsentasi $\mathrm{NaCl}$, maka ion $\mathrm{Na}^{+}$semakin banyak sehingga $\mathrm{NaOH}$ yang terbentuk pun semakin banyak. Dengan semakin banyaknya $\mathrm{NaOH}$ di dalam larutan akan membuat larutan akan cenderung semakin basa yang diindikasikan dengan semakin tingginya $\mathrm{pH}$ akhir larutan.

Dengan semakin tingginya tegangan pada konsentrasi yang sama, maka $\mathrm{pH}$ larutan akan semakin menurun. Menurunya $\mathrm{pH}$ larutan akhir pada penelitian ini dikarenakan adanya reaksi samping yang dapat membentuk produk-produk lain seperti hipoklorit, klorat, dan lain-lain. Adapun mekanisme reaksi pembentukan produk samping antara lain sebagai berikut (Bommaraju dkk, 2011; Abdel-Aal dan Hussein, 1993):

a. Pembentukan Hipoklorit $\mathrm{Cl}_{2}+2 \mathrm{NaOH} \rightarrow \mathrm{NaOCl}+\mathrm{NaCl}+\mathrm{H}_{2} \mathrm{O}$

b. Pembentukan Klorat $3 \mathrm{NaOCl} \rightarrow \mathrm{NaClO}_{3}+2 \mathrm{NaCl}$

c. Pembentukan Hipoklorit $\mathrm{NaCl}+\mathrm{H}_{2} \mathrm{O} \rightarrow \mathrm{NaOCl}+\mathrm{H}_{2}$

d. Pembentukan Asam Klorida $\mathrm{Cl}_{2}+\mathrm{H}_{2} \mathrm{O} \rightarrow \mathrm{HCl}+\mathrm{HClO}$

e. Pembentukan Klorat $\mathrm{NaCl}+3 \mathrm{H}_{2} \mathrm{O} \rightarrow \mathrm{NaClO}_{3}+3 \mathrm{H}_{2}$

f. Pembentukan Klorat $3 \mathrm{Cl}_{2}+6 \mathrm{NaOH} \rightarrow \mathrm{NaClO}_{3}+5 \mathrm{NaCl}+3 \mathrm{H}_{2} \mathrm{O}$

Dengan terbentuknya produk samping di atas dapat membuat $\mathrm{pH}$ larutan berkurang karena terbentuknya senyawa-senyawa asam seperti hipoklorit dan klorat. Selain itu, penurunan $\mathrm{pH}$ dapat pula terjadi karena adanya reaksi samping antara $\mathrm{NaOH}$ dan $\mathrm{Cl}_{2}$ yang menyebabkan jumlah $\mathrm{NaOH}$ semakin berkurang, begitu pula dengan pH nya. Reaksi samping ini terjadi karena tidak adanya pemisah antara anoda dan katoda.Reaksi samping berlangsung saat ion-ion bebas berada di dalam larutan dan memicu terjadinya reaksi pembentukan produk samping. Hal tersebut menyebabkan produksi gas klor menjadi sedikit dan selektivitas produknya menjadi berkurang. 
Perbandingan Konsumsi Energi antara Elektrolisis dan Elektrolisis Plasma

Proses elektrolisis dan proses elektrolisis plasma dalam percobaan ini dilakukan pada reaktor dan kondisi operasi yang sama kecuali pada tegangan. Untuk proses elektrolisis tegangan diberikan sebesar $50 \mathrm{~V}$, sementara untuk elektrolisis plasma sebesar $400 \mathrm{~V}$.

Tabel 1 menunjukkan kenaikan konsentrasi $\mathrm{NaCl}$ dalam larutan menurunkan Konsumsi energi per mmol produk $\mathrm{Cl}_{2}$ baik pada proses elektrolisis maupun elektrolisis plasma. Rasio antara harga konsumsi energi per mmol produk $\mathrm{Cl}_{2}$ elektrolisis dan elektrolisis plasma meningkat tajam dengan bertambahnya konsentrasi $\mathrm{NaCl}$. Hal ini terjadi karena pada konsentrasi tinggi menyebabkan pembentukan plasma yang meningkat secara signifikan ditandai dengan semakin besarnya plasma yang terbentuk.

Dari hasil yang diperoleh pada Tabel 1 menunjukkan bahwa metode elektrolisis plasma dapat menurunkan konsumsi energi hingga 38 kali lebih rendah dibandingkan dengan elektrolisis. Hal ini disebabkan oleh aktifitas radikal yang terbentuk karena proses pembentukan plasma pada elektrolisis ini. Pada proses elektrolisis plasma terdapat spesi aktif foton yang mampu melakukan crosslinking dengan cara menghasilkan matriks molekular dua atau tiga dimensi dengan membentuk ikatan-ikatan antara molekul-molekul atau polimer yang berdekatan (Gao dkk, 2008). Matriks molekular dua atau tiga dimensi yang dimaksud adalah senyawa radikal yang akan bereaksi dengan radikal lain dengan membentuk ikatan antar molekul berdekatan (Yan dkk, 2009). Dengan terbentuknya spesi aktif radikal tersebut, akan membuat mekanisme pembentukan suatu senyawa menjadi lebih cepat sehingga jumlah produk yang dihasilkan pun lebih banyak.
Mekanisme dekomposisi $\mathrm{NaCl}$ menjadi gas klor dapat menggunakan metode elektrolisis. Metode ini akan memecah komponan $\mathrm{NaCl}$ menjadi ion-ion $\mathrm{Na}$ dan $\mathrm{Cl}$. Berikut ini adalah mekanisme reaksi dari elektrolisis $\mathrm{NaCl}$ di dalam larutan (Santorelli dkk, 2009):

Reaksi pada anoda :

$2 \mathrm{Cl}^{-(\mathrm{aq})} \rightarrow \mathrm{Cl}_{2(\mathrm{~g})}+2 \mathrm{e}^{-}$

Reaksi pada katoda :

$2 \mathrm{Na}^{+}{ }_{(\mathrm{aq})}+2 \mathrm{H}_{2} \mathrm{O}+2 \mathrm{e}^{-} \rightarrow \mathrm{H}_{2(\mathrm{~g})}+2 \mathrm{Na}^{+}{ }_{(\mathrm{aq})}+$ $2 \mathrm{OH}_{(\mathrm{aq})}$

Reaksi total :

$2 \mathrm{NaCl}_{(\mathrm{s})}+2 \mathrm{H}_{2} \mathrm{O}_{(\mathrm{l})} \rightarrow 2 \mathrm{NaOH}_{(\mathrm{aq})}+\mathrm{Cl}_{2(\mathrm{~g})}+\mathrm{H}_{2(\mathrm{~g})}$

Pada penguraian senyawa $\mathrm{NaCl}, \mathrm{Cl}^{-}$ yang terbentuk akan berubah menjadi klor radikal akibat adanya eksitasi elektron dan juga reaksi dengan $\mathrm{OH}$ radikal dari proses elektrolisis plasma. Dua klor radikal akan bereaksi satu sama lain dan membentuk suatu senyawa klor $\left(\mathrm{Cl}_{2}\right)$. Jin dkk. (2010) mengusulkan mekanisme pembentukan spesi aktif radikal klor pada reaksi elektrolisis plasma pada larutan $\mathrm{NaCl}$ adalah sebagai berikut :

$\mathrm{Cl} \rightarrow \mathrm{Cl} \bullet+\mathrm{e}^{*}$

$\bullet \mathrm{OH}+\mathrm{Cl}^{-} \rightarrow \mathrm{Cl} \bullet+\mathrm{OH}^{-}$

$\mathrm{Cl} \bullet+\mathrm{Cl} \bullet \rightarrow \mathrm{Cl}_{2}$

$\mathrm{Cl}_{2}+\mathrm{H}_{2} \mathrm{O} \rightarrow \mathrm{HCl}+\mathrm{HClO}$

$2 \mathrm{HClO}+\mathrm{H}_{2} \mathrm{O}_{2} \rightarrow 2 \mathrm{Cl}^{+}+\mathrm{O}_{2}+2 \mathrm{H}^{+}$

Selain membentuk gas klor, terdapat produk samping seperti asam Hipoklorit.HClOyang terbentuk pada persamaan (13) selanjutnya bereaksi dengan $\mathrm{H}_{2} \mathrm{O}_{2}$ menghasilkan $\mathrm{H}^{+}$dan $2 \mathrm{Cl}^{-}$.

Tabel 1. Konsumsi Energi per mmol $\mathrm{Cl}_{2}$ Produk antara Proses Elektrolisis dan Proses Elektrolisis Plasma pada Larutan $\mathrm{NaCl}$ Selama 15 Menit Proses

\begin{tabular}{cccccc}
\hline \multirow{2}{*}{$\begin{array}{c}\text { Konsentrasi NaCl } \\
(\mathrm{mol} / \mathrm{L})\end{array}$} & \multicolumn{2}{c}{ Konsumsi Energi Listrik $(\mathrm{kJ})$} & \multicolumn{2}{c}{$\begin{array}{c}\text { Konsumsi Energi per Satuan } \\
\text { Produk, Wr }\left(\mathrm{kJ} / \mathrm{mmol} \mathrm{Cl}_{2}\right)\end{array}$} & \multirow{2}{*}{ Rasio } \\
\cline { 2 - 5 } & Elektrolisis & $\begin{array}{c}\text { Elektrolisis } \\
\text { Plasma }\end{array}$ & Elektrolisis & $\begin{array}{c}\text { Elektrolisis } \\
\text { Plasma }\end{array}$ & \\
\hline 0.05 & 30.2 & 373.5 & 9277 & 988 & 9 \\
0.1 & 45.7 & 439.7 & 9616 & 510 & 19 \\
0.15 & 65.5 & 410.4 & 10912 & 284 & 38 \\
\hline
\end{tabular}


Ion-ion klor yang terbentuk dari reaksi tersebut selanjutnya akan membentuk senyawa klor $\left(\mathrm{Cl}_{2}\right)$. Dengan demikian mekanisme pembentukan senyawa klor pada proses elektrolisis plasma terjadi atas dua cara, yaitu melalui rekombinasi klor radikal (Cl•) dan ion klor ( $\left.\mathrm{Cl}^{-}\right)$seperti yang ditunjukkan pada persamaan (12) dan (7).

\section{KESIMPULAN}

Aplikasi metode elektrolisis plasma terbukti dapat diterapkan pada proses produksi klor-alkali. Semakin tinggi tegangan dan semakin besar konsentrasi, maka produksi gas klor semakin meningkat dan konsumsi energi persatuan produk yang dihasilkan semakin rendah.

Kedalaman anoda berhubungan dengan luas permukaan kontak anoda dengan larutan $\mathrm{NaCl}$. Semakin dalam anoda maka semakin besar plasma yang terbentuk sehingga semakin rendah konsumsi energi listrik per mmol gas klor yang dihasilkan.

Konsumsi energi terendah dari proses elektrolisis plasma adalah sebesar 284,51 $\mathrm{kJ} / \mathrm{mmol} \mathrm{Cl}_{2}$ atau 38 kali lebih rendah dibandingkan dengan elektrolisis pada konfigurasi reaktor yang sama.

\section{UCAPAN TERIMA KASIH}

Penelitian ini didanai oleh Osaka Gas Foundation of International Culture Exchange Anggaran Tahun 2011/2012.

\section{DAFTAR PUSTAKA}

Euro Chlor, The European Chlor-Alkali industry: An Electricity Intensive Sector Exposed to Carbon 2010, http://www.eurochlor.org/media/9385/3-2the_european_chlor-alkali_industry__an_electricity_intensive_sector_exposed_to_ca rbon_leakage.pdf (akses 18 Oktober 2012).

Bommaraju, T.V.; Orosz, P. J.; Sokol, E. A., Brine Electrolysis, 2007, http://electrochem.cwru. edu/encycl/art-b01-brine.htm (akses 23 Februari 2011).

Abdel-Aal, H. K.; Hussein, I. A., Parametric study for saline water electrolysis: part Ihydrogen production, International Journal of Hydrogen Energy, 1993, 18(6), 485-489.
Santorelli, R. L.; Schervan, A.; Delfrate, A., Energy production from hydrogen cogenerated in chlor-alkali plants by the means of PEM fuel cells systems, Chemical Engineering Transactions, 2009, 12, 715-720.

Saksono. N.; Feriansyah, R,; Bismo, S., Hydrogen Production Using Non-Thermal Plasma Electrolysis in $\mathrm{KOH}$ Solution, The $12^{\text {th }}$ Internasional Conference on Quality in Research, Bali, 4-7 Juli 2011, 112-118.

Mizuno, T.; Akimoto, T.; Azumi, K.; Ohmori, T.; Aoki, Y.; Takahashi, A., Hydrogen evolution by plasma electrolysis in aqueous solution, Japanese Journal of Applied Physics, 2005, 44(1A) 2005, 396-401.

Jin, X. L.; Wang, X. Y.; Zhang, H. M.; Xia, Q.; Wei, D. B.; Yue, J. J., Influence of solution conductivity on contact glow discharge electrolysis, Plasma Chemistry and Plasma Processing, 2010, 30(3), 429-436.

Moustakas, K.; Fatta, D.; Malamis, S.; Haralambous, K.; Loizidou, M., Demonstration plasma gasification/vitrification system for effective hazardous waste treatment, Journal of Hazardous Materials, 2005, 123(1-3), 120126.

Sengupta, S. K.; Singh, O. P., Contact glow discharge electrolysis: a study of its chemical yields in aqueous inert-type electrolytes, Journal of Electroanalytical Chemistry, 1994, 369(1-2), 113-120.

O'Brien, T. F.; Bommaraju, T. V.; Hine, F., Handbook of Chlor Alkali; Springer: New York, 2005; hlm.17-35.

Gao, J.; Wang, A.; Fu, Y.; Wu, J.; Ma, D.; Guo, X.; Li, Y.; Yang, W., Analysis of energetic species caused by contact glow discharge electrolysis in aqueous solution, Plasma Science and Technology, 2008, 10(1), 30-38.

Yan, Z. C.; Li, C.; Lin, W. H., Hydrogen generation by glow discharge plasma electrolysis of methanol solutions, International Journal of Hydrogen Energy, 2009, 34(1), 48-55. 